\title{
兵庫県南部地震の衛星画像に見られる線状な谷地形の分布
}

\section{Distribution of Linear Structure of Valley in Satellite Images of Hyogo-ken Nanbu (South) Earthquake}

\author{
古宇田亮一* \\ Ryoichi Kouda
}

\begin{abstract}
A big earthquake hit Kobe and North Awaji to kill over 5,000 people and to damage many constructions. We received many satellite image data and the related information taken around the date of the earthquake. The high resolution data transfer from the data distribution organization to the end-user was so fast within three days after the earthquake at the fastest case, and within about one month mostly. The analytical procedure in the laboratory delayed because of the many tasks for the data preprocessing. We need more than half a day for the output of one scene even to make the simple hard copy for the visual interpretation. The worst problem in images is the invisible ground surface caused by clouds, foggy or humid atmosphere, or microwave noise. Even SAR data had some noisy invisible parts. Usually geologists do not use the image data which include the saturated white noisy stripes on some parts of the scene caused by some artificial source on the ground. Many of the optical sensors like MESSR and SPOT were not so useful in the cloudy condition. JERS-OPS stereoscopic image data can not provide the useful analysis around the active fault. SPOT satellite data frequently used for the initial analysis because of the higher resolution and the quick delivery as the satellite-born data. The dynamic range of SPOT data are not enough to analyze the surface structure. The interferometric data of paired SAR data help the centimeter order analysis of surface topographic change in regional view. TM data provided lower ground resolution but the higher dynamic range is interested in looking at the regional structure of active faults. The best resolution can be taken in the image of INTER COSMOS KV-1000 that provides the detailed interpretation of the road and other artificial constructions or automobiles, though the dynamic range in the mountain region of the image were very low in the value. Comparative study of JERS-SAR and LANDSAT-TM images suggests that the earthquake faults are very clear in the continuity and the contrast in images but other lines and circle-like structures of valley are not much concordant to each other. The discordant of the extracted structure between SAR and TM is caused by the different direction of sunlught and microwave illumination with about 45 degree difference of direction. It is also suggested that the dynamic range of the brightness of images is much more important and useful specification to analyze the structure in images than the higher ground resolution.
\end{abstract}

\section{1.はじめに}

1995年 1 月 17 日の兵庫県南部地震は，5000人以上の 死者を出す大惨事となった都市域地震であると同時 に，建設工学的，都市工学的，地盤工学的，地質学的 な様々な課題を投げかけた。とりわけ，地質学的には， 直下型地震が接近しつつあることが予想されていたに

\section{*地質調查所}

「写真測量とリモートセンシング」Vol. 34，No. 6， 1995
もかかわらず，充分な観測体制も警戒体制もとれず， 一般市民への広報もほとんどなされなかった。筆者も， 当該地域のデー夕の収集に携わっていた。被害の深刻 さ以上に，地震予知の研究に携わっていたのではない にせよ，事前に何もできなかったことは慗愧に堪えな い。これがわが国における地盤研究の現状であるとす れば，筆者も含めて猛省する必要があろう。

兵庫県南部地域では，今回の震源とほぼ同じ淡路島 北端で1916年11月26日に M6.1の地震が発生した。こ の時の被害は軽微だったせいか，地元住民の記憶に残 らなかったようである。兵庫県南部地域では多数の活 
断層が走り, 地盤のゆるい平野部に人口が密集, 活断 層域に新幹線やダムが設けられる等のため, 地盤工学 的対策が必要とされていた。開発の進展に伴い, 主に 建設工学的に地盤データが収集されてきた。今回の地 震発生による対策を通じて, 活断層や都市地下地盤に ついての地質学的デー夕が飛躍的に多く収集されるこ とになるであろう。筆者が関係する都市地盤の数值解 析による将来予測も進展するに違いない。一方, 日本 のふよう 1 号によるインターフェロメトリデータも公 開され(政春, 1995 ${ }^{1)}$ ), GPS 設置場所の新設も相次ぎ, 平面的な地盤変動モニタリングが一層進展すると期待 されている(海津, 他, 19952) 夕が収集される段階では, 分解能の低い衛星画像に頼 る割合は低くなるかもしれない。しかし，わが国にお いてさえ，これほど多量のデータが収集できる所は極 めて限られている。従って, この地域の衛星画像によ る概略的観測結果を解析することは, 他の地域の解析 を進める上でも有用であると考えられる。ここでは,
線状に分布する谷地形が衛星の光学センサ画像とマイ クロ波画像の間でどのように異なるかを考察して, 今 後の衛星画像活用への一助になればと思い小論を以下 に報告する。

\subsection{5年兵庫県南部地震前後の画像}

兵庫県南部地震前後の衛星画像デー夕のうち, 解析 に利用したのは, 日本のふよう 1 号 (JERS) 衛星の光 学センサ (OPS) と合成開ロレーダ (SAR) 及び, 海 洋観測衛星 (MOS-1) の MESSER, 欧州宇宙機関の ERS-1衛星の AMI, フランスのSPOT 衛星の PD と $\mathrm{XS}$ ，アメリカの LANDSAT 衛星のTM, ロシアの INTER COSMOS 衛星の KV-1000である。また, 空 中写真も参考にした。データ・アクセスは, デー夕配 布機関と共同だったため, 非常に早い。最初に磁気テー プデータが配布機関に届いたのが発災後 3 日であった という。震災前を含む多くのデータが, 筑波の研究所

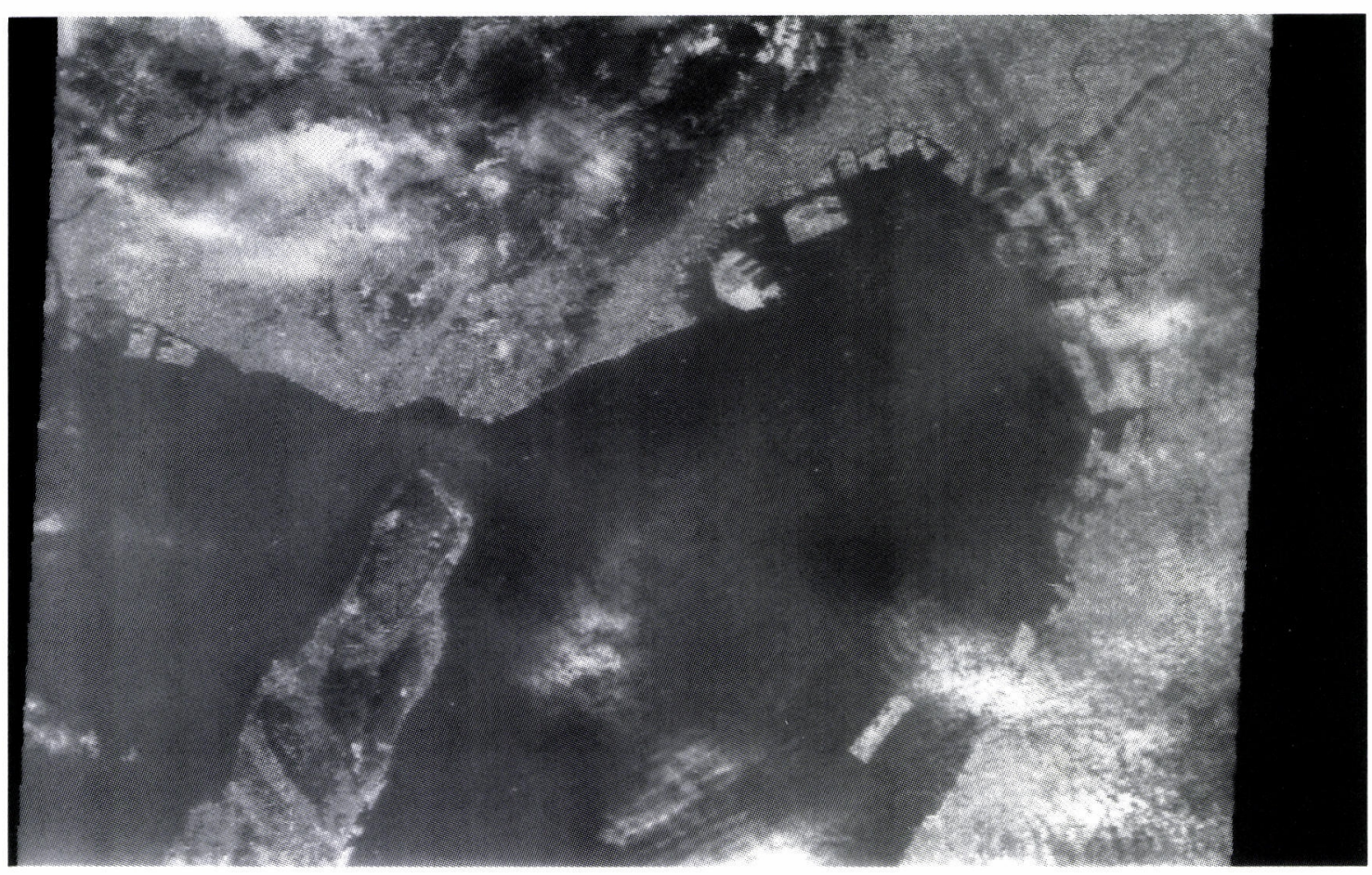

図 1.SPOT衛星画像（パンクロマティック）1995 年 1 月 20 日P 322-R 280 震災地域以外の雲と霞が多く, 通常このような画像を解析に用いない。

Figure 1. SPOT Panchromatic image of 1995-01-20 (P322-R280). Cloud and smoky moistures are abandant especially outside of the earthquake area. The image is not usually used for the analysis. Copyright of original image data is held by SPOT IMAGE (1995) through NASDA/RESTEC. 


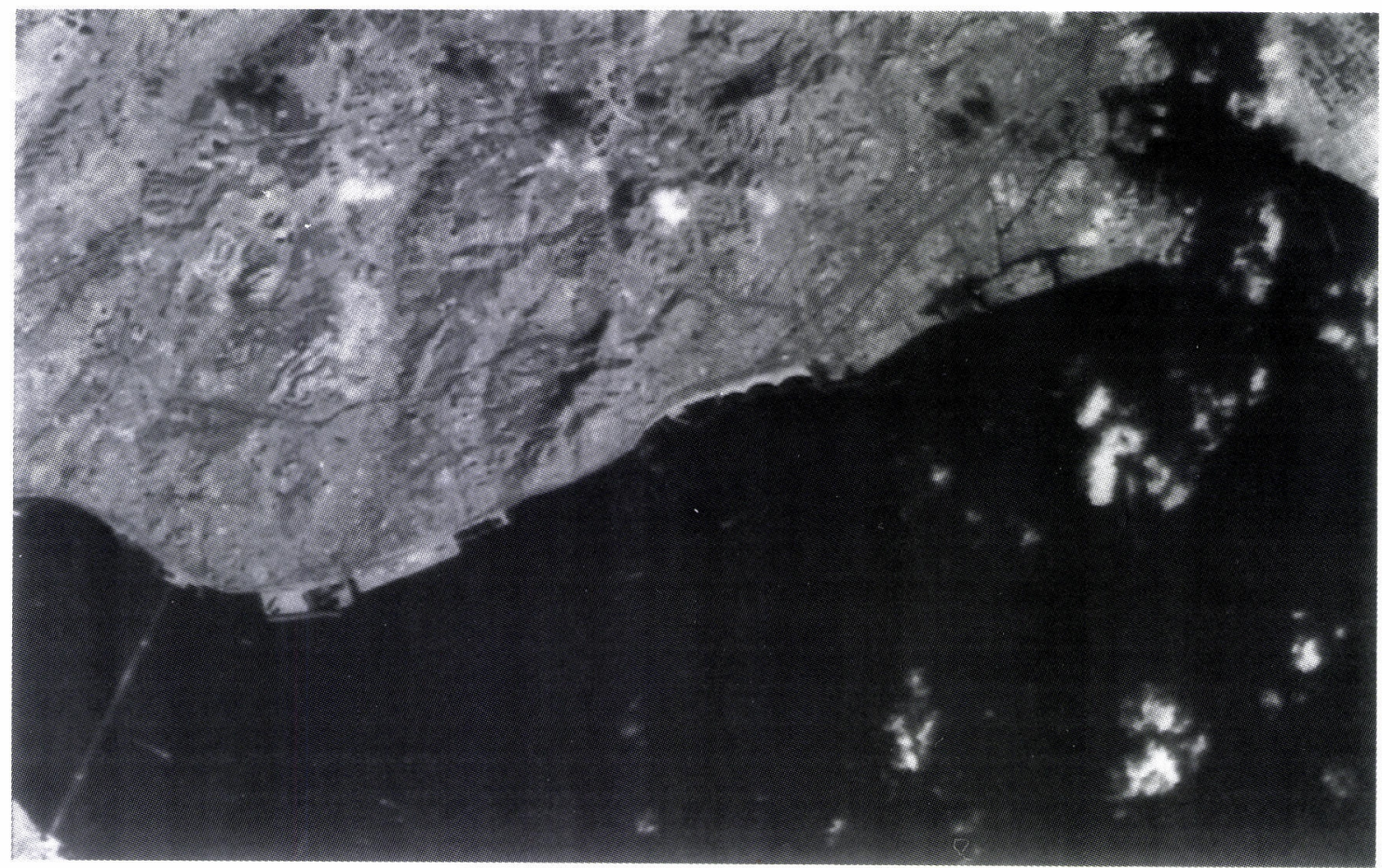

図 2. TM画像 1995 年 1 月 24 日P 110-R 036 (神戸一明石地域) RGBに 5, 4, 7 バンドを割り当てた。都市域はほとんど 解析に向いていない。明石海峡大橋が明瞭に見えるのはコントラストが強いため。分解能 $30 \mathrm{~m} 。$ 縦 $12 \mathrm{~km}$ 横 19.2 $\mathrm{km}$ 。

Figure 2. LANDSAT TM image of 1995-01-24 (P110-R036) at Kobe-Akashi area. Bands 5, 4, and 7 are assigned to red, green, and blue respectively. The city area is not good for the analysis. The Akashi bridge as small as under $30 \mathrm{~km}$ is clearly seen by the higher contrast with dark sea surface. The image is $12 \mathrm{~km}$ for the vertical and $19.2 \mathrm{~km}$ for the horizontal sizes. Coutesy by NASDA/RESTEC for the original data.

に発災後一ヶ月程度で届けられた。

問題は解析の遅れである。これまでに可能性として は検討されていたはずであったが，実際に大規模な地 震災害が発生すると, これまでの研究向きの体制では 明かに不備がある。データを単純にプリントにするだ けでも, 磁気テープから一旦ネットワーク経由で時間 をかけて解析装置に送り，使いやすい形に蓄積して， データに合わせてハードコピーを取る。この作業だけ でも一巻あたり半日以上かかった。今回は, 一度に数 巻ずつ来るので, 解析が追いつかない。最も大きな問 題は, 地上が見えにくいことであった。MOS-MESSER や, SPOT, TM データのような光学センサ画像 では, 雲や霞があると使いにくい。通常, 地質学的解 析では, 雲のある画像は, 始めから使わない。地震災 害では, 地震発生に直近の画像に雲の多いことがあり, どのように使うかが新しい課題となる。また，合成開 ロレーダー (SAR) 画像は, 雲を貫く全天候型である
ものの，ふよう 1 号画像では，電波ノイズの障害が出 る場合があって，必ずしも適切なものが得られたわけ ではない。

SPOT 画像はいち早く届いて, 頻繁に使われた。し かし,山間部のダイナミックレンジが低いものが多く, 詳細な地質構造解析に難があった(図 1)。ふよう1号 のSAR 画像は, 構造が見やすい。また, 震災前後の データを干渉合成（インターフェロメトリー）方るこ とにより，衛星からの視線方向の $\mathrm{cm}$ オーダーのずれ を検出することができた (海津他，1995 2) $)$ ので，今後 の活用が大いに期待できよう。子よう 1 号-OPS 立体 視のデー夕も期待されたが, 実デー夕は雲が多く, 夕゙ イナミックレンジが低いため, 即時的には, 有効では なかった。分解能の点から言之ば, ロシアの KV-1000 が地上 $2 \mathrm{~m}$ と高分解能なので, 空中写真に匹敵し, 事 実, 道路上の自動車が良く識別できた。しかし, 地質 学的解析のためにはダイナミックレンジが低く, 山岳 


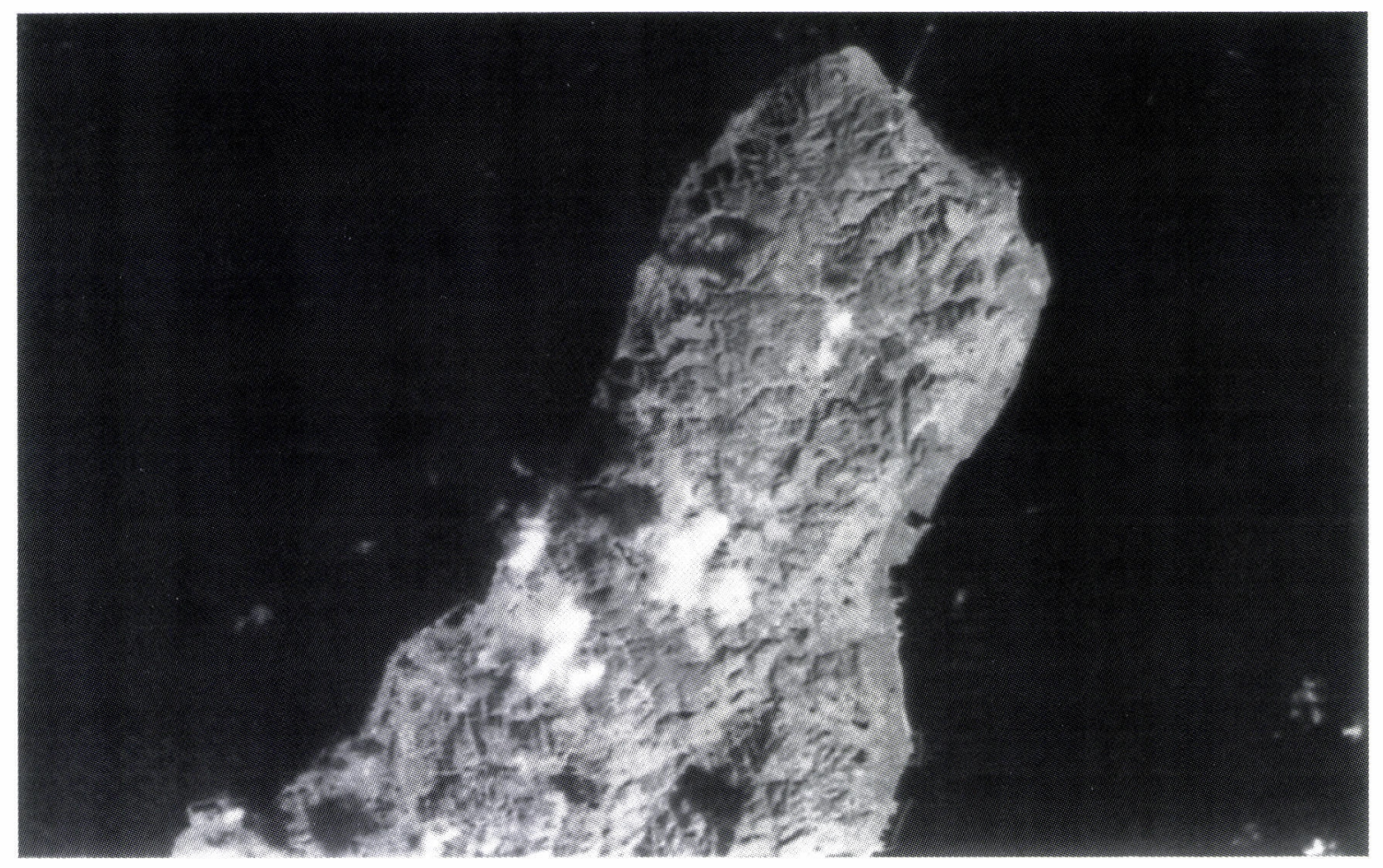

図 3. TM画像 1995 年 1 月 24 日P 110-R 036(淡路島北部) RGBに 5, 4, 7 バンドを割り当てた。山間部の地形が明瞭で, 地震断層も鮮明。縦 $12 \mathrm{~km}$ 横 $19.2 \mathrm{~km}$ 。

Figure 3. TM image of 1995-01-24 (P110-R036) at North Awaji. Bands 5, 4, and 7 are assigned to red, green, and blue respectively. The geomorphic structure in the low mountain range is clear. Erathquake faults are also clear along the coast line of the East and the West. The image is $12 \mathrm{~km}$ for the vertical and $19.2 \mathrm{~km}$ for the horizontal sizes. Coutesy by NASDA/RESTEC for the original data.

域の詳細な地質構造や，地震断層に関係しそうな要素 を抽出するには不向きであった。TM画像は分解能が $30 \mathrm{~m}$ と粗いものの，1月24日に比較的鮮明な画像がと れ，ダイナミックレンジも広かったので, 山間部の解 析には使い易い(図 2, 3 )。衛星画像は, 多くの分野 の情報を含む。液状化現象や地滑り域等の情報が抽出 できている。しかし，有効に活用可能と言えそうなも のは地震断層の動きに関する情報であろう。地震断層 の衛星画像による解析には，まだ困難なことが多く， 今後, 解析手法を高努力必要としているだろう。

\section{3. 地震断層ととの他の線状谷地形の分布}

神戸市域における断層は，六甲山系におけるものを 除くと, 衛星画像では明暸ではない。いち早く配布さ れた SPOT 衛星画像でも, 被災地域の衛星画像上の構 造的, 分光的特徵は, 道路や建物等の人工構造物が主
であって地盤についての情報に乏しく，雲や霞が多い (図 1)。六甲山系以北では，ほとんど動きが把めてい ない。そこで，震源に近く，余震分布も集中した淡路 島北部の線状模様を解析した。ここでは，主に地盤の 弱線を示す谷地形を抽出した。谷地形は, 太陽や電波 の照射方向（レンジ方向）に斜交する線状の地形の示 す輝度レベル D が，照射に近い方が影 $\mathrm{D}_{1}$ で，遠い方が 明 $\mathrm{D}_{2}$ の)輝度を示し $\left(\mathrm{D}_{1}<\mathrm{D}_{2}\right)$, 線状に並ぶ時に判断さ れる。

雲の少ないSPOT 衛星画像の地震前(1991年10月23 日）と地震後（1995年 1 月20日）を比較した限りでは， 淡路島北部の線状模様に特に大きな変化は見られな い。SPOT 画像のダイナミックレンジが山間部で狭い ため，判読上は不利である。一方，TM 画像（1995年 1 月24日；四 3 ）に見られる線状模様は極めて明瞭で ある(図 4)。雲が一部を被覆しているものの, 地震断 層は東部と西部で明瞭であり，西部の野島断層では， 


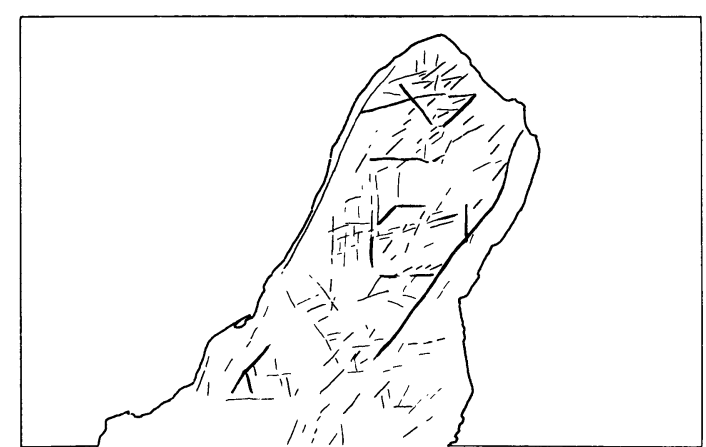

図 4.図 3 の画像から線状谷地形を抽出。太線は特に明 瞭な谷地形である。縦 $12 \mathrm{~km}$ 横 $19.2 \mathrm{~km}$ 。

Figure 4. Linear structure of valley extracted from Figure 3. The thick solid lines are the clearer in the valley structure. This is $12 \mathrm{~km}$ for the vertical and $19.2 \mathrm{~km}$ for the horizontal size.

やや雲の影等で見えにくい。北部では地震断層に並行 してほぼ同じ向きの谷地形と，それに斜交して，北部 の海岸線の NW-SE 系と並行する構造及び東西系に 近い谷地形が卓越する。ところが，その南隣の山間域 では，南北系と東西系の谷地形が目立っており，東西 の海岸域における地震断層は明瞭で連続性もよいの に，山間部では短く数本しか見られない。更に南の余 震域の端になると，雲と影の影響も強くなり連続性の 良い明瞭な谷地形が見られなくなる。連続性の良い明 瞭な直線的谷地形が最近における地震断層を示すもの とは必ずしも言えないが，少なくとも淡路島北部の山 間部の侵食がこの谷地形に沿う弱線上で著しいことを 示しており，かつ山間部の隆起も想定できる。神戸地 域が全体として東西系の圧縮を受けており，淡路島北 部がその歪の集中し得る場所と考えることに調和的で あろう。TM 画像上では，貫入活動に伴うものと思わ れる円環状構造も抽出でき(図 5 ), 興味深い。しかし, その意味するところは衛星画像のみでは不明であり, 今後の地下探査に期待される。

ふよj 1 号の SAR 画像 (1995年 2 月 6 日) では, 淡 路島北部に衛星進行方向に直交するレンジ方向にやや 規則的なノイズ縞があらわれている(図6)。これは画 像判読上好ましくない。宇宙開発事業団からノイズを とった画像が配布されたが，その効果がどれほどの副 作用をもたらすか不明であり，それも参照しつつ通常 配布の画像を解析した(図 7 )。山間部のフォアショー

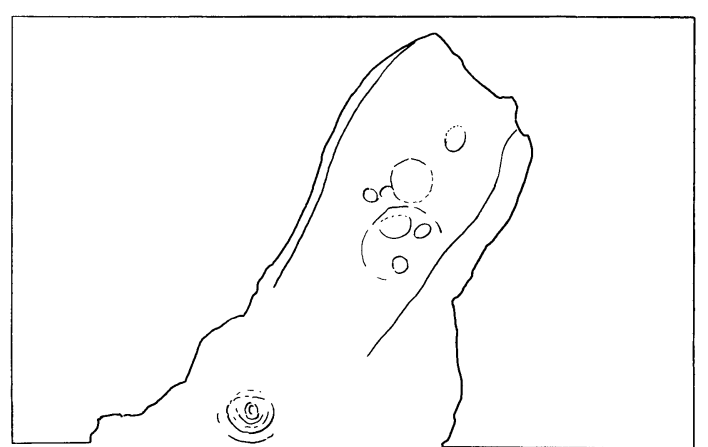

図 5. 図 3 の画像から円環状構造を抽出。島の東と西の 直線的構造は今回動きの確認された地震断層で, 図 4 と同じ。縦 $12 \mathrm{~km}$ 横 $19.2 \mathrm{~km}$ 。

Figure 5. Circle-like structures extracted from Figure 3. Earthquake faults are depicted in the solid lines of the East and the West of the island. This is 12 $\mathrm{km}$ for the vertical and $19.2 \mathrm{~km}$ for the horizontal sizes.

トニング効果はあまり大きくないことから，地形歪補 正はしていない。歪補正すると，その副作用が生じや すいからである。困 7 では，図 4 にみられた東西方向 の構造が明瞭ではない。代わりに，地震断層に並行す る構造とそれに直交〜斜交する構造がやや明瞭であ る。その他で両者が一致する抽出線は必ずしも多くは ない。罒 5 に示される円環状構造も見之難い。

両者の解析結果の違いは, 以下の要因が考えられる。 (1)太陽照射角度が衛星からの電波照射角度より低くな るため, TM 画像の谷地形コントラストの方が明 瞭。

(2)照射方向の違いにより強調される谷地形の見え方が 変わる。

(3) 2 週間の撮影時期の違い。

(4)スペクトル反射と後方散乱の違いによる斜面の見之 方の違い。

以上のうち, (1)は異なる時期の TM 画像でも多く観 察され，太陽照射高度によって影のつき方に差が出る ことが既にわかっているが，これほど明瞭には異なら ない。(2)は，少し照射方向が異なることで，線状模様 のパターンに違いが出ることがよく知られており, こ こでは45度近い違いがあるため，最も可能性が高い。 TM 画像では地震断層にほぼ直交する南東方向から 照射されており，図 4 にも地震断層に並行する方向が いくつか抽出されているのは照射に直交する方向によ る強調効果のためであろう。困 7 では地震断層に並行 


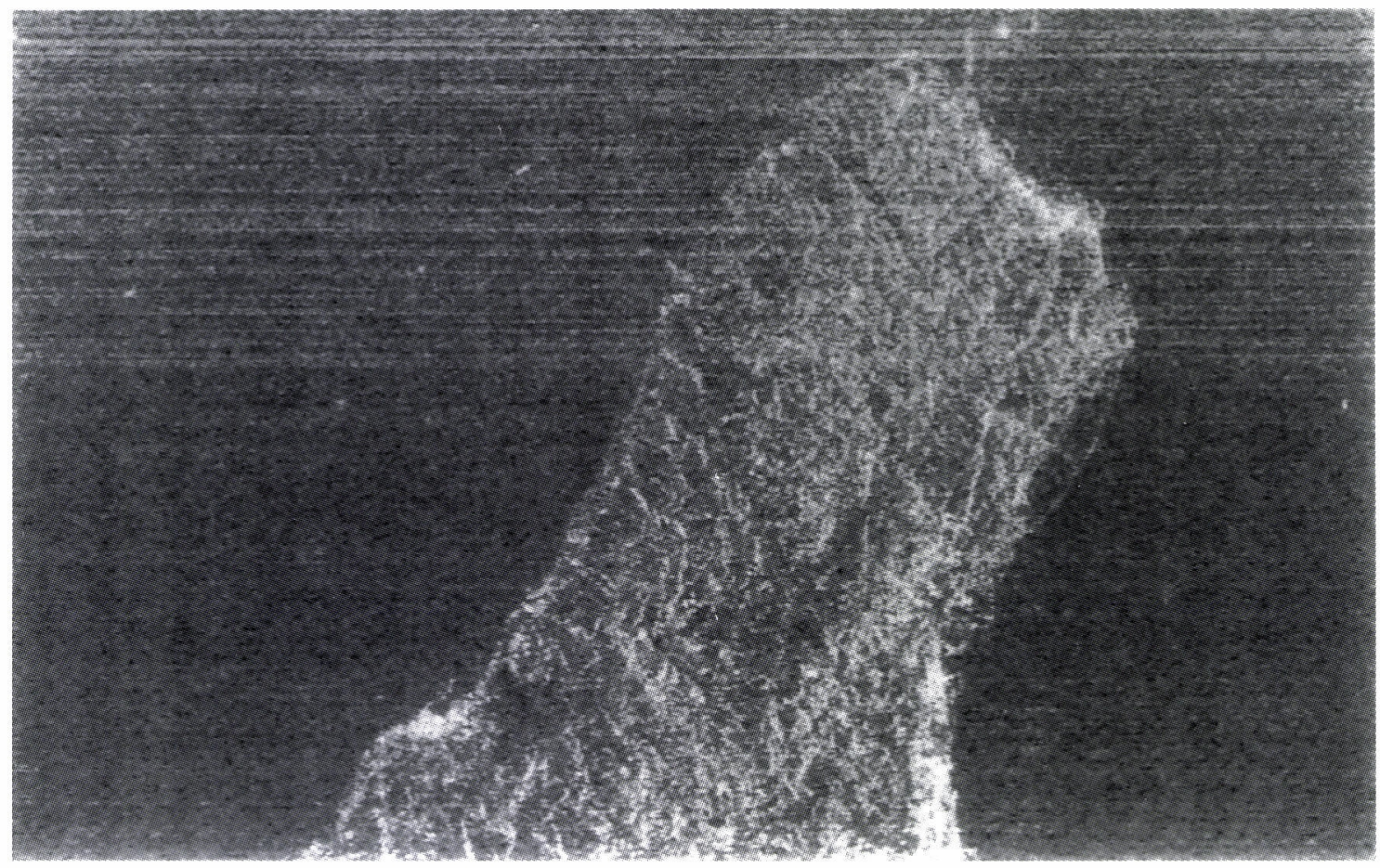

図 6.ふよう 1 号SAR画像 1995 年 2 月 6 日D 072-243(淡路島北部)。北端に電波ノイズがレンジ方に見られる。明石 海峡大橋は, SAR特有のアジマス方向の直線的輝線と橋中央のブライトスポットが見える。縦 $10 \mathrm{~km}$ 横 $16 \mathrm{~km}$ 。

Figure 6. JERS SAR image of 1995-02-06 (D072-243) at North Awaji. The noise lines along the range direction interfere the north of the Awaji island. Bright line and spot are observed at the Akashi Bridge at the north edge of the island. The image is $10 \mathrm{~km}$ for the vertical and $16 \mathrm{~km}$ for the horizontal sizes. MITI/NASDA retains the ownership, 1995.

する方向の谷地形が図 4 ほど明瞭ではない。むしろ南 北系の抽出線が多いのは, 照射が東西系に近いためで あろう。東西系の構造は図 7 にほとんど抽出できず， 予想通り見えにくいのである。眓 4 の太陽照射方向に 並行する谷地形も見えにくいが，北端では見えるもの もある。しかし，図７では明瞭に見えており，照射方 向の違いが大きいといえる。(3)と (4)は物性の意味が異 なるために, 単なる㓌影以外の情報に左右される場合 であるが，山間部では院影を上まわる効果は期待しに くいと考えられる。

一般には, 衛星 SAR 画像と衛星光学センサ画像か ら抽出される線状谷地形の違いは, 照射方向の違いで 説明可能と思われる。しかし, 円環状構造が SARにお いて見えにくいことは, 後方散乱の特性になるかも知 れない。この地域では, 地震断層が右ずれ系であり, 北東向きに開いた JOG 型の断層分布が想定されるが, 実際，図 4 でも北端の中央やや西よりに，それと思わ

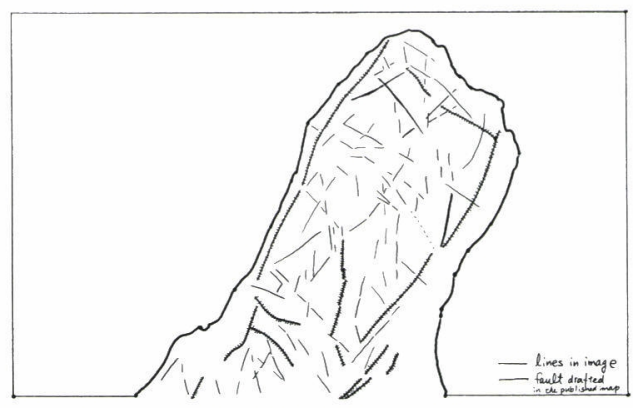

図 7.図6の線状谷地形判読図。

太線に斜交線を入れた線は地質図（藤田他， $1984^{3)}$; 水野他, 19904) )に示された断層位置。海岸 線は図 6 からあえて選んだ概略で, 実際とは少し 異なる。縦 $10 \mathrm{~km}$ 横 $16 \mathrm{~km}$ 。

Figure 7. Linear structure of valley extracted from Figure 6. The thick solid lines with ticks are the active faults shown in the geological maps (Hujita et al., 1984 ; Mizuno et al., 1990). The coastal line is more or less different from the true line because of the ambiguous image. This is $10 \mathrm{~km}$ for the vertical and $16 \mathrm{~km}$ for the horizontal sizes. 
れる雁行する線状構造が見られる。しかし，図７の SAR 画像における同一地域ではこれも不鮮明であり， 分解能が高いと言う理由だけで SAR 画像の解析を優 先することは躊躇されるだろう。以上の諸点は，今後 の解析を発展させる上で看過できない要点である。

\section{4.おわりに}

衛星画像から地質学的に有意味であると考えられる 構造を抽出するため, 谷地形に注目して, 特に山間部 の構造が見易いふよう 1 号衛星 SAR 画像と TM 画像 の淡路島北部域を比較解析した。その結果, 地震断層 は極めて明瞭であったが，その他の線状谷地形は必ず しも一致するものばかりではなく，TM 画像に見える 円環状構造や雁行する線状構造はSAR 画像で不明で あった。一致しない理由の多くは，今回の例では照射 方向が45度に近く離れているためと考えられる。これ は，航空機 SAR 画像における傾向と異なる点である。 衛星 SAR 画像はコントラストが大きく，これまで地 質地形構造を解析するのに有利と考えられていたが, マイクロ波の性質において不明な点を含み，現状の性 能では不十分であることも明らかであろう。分解能よ クダイナミックレンジに優るデータの方が自然の構造 を調べるのに有効である。

本研究では, 地球環境観測委員会 (坂田俊文委員長) の兵庫県南部地震タスクフォース $(\mathrm{TF})$ の下に宇宙開 発事業団と（財）リモート・センシング技術センター から提供していただいた右のデー夕を中心に, 解析を 進めている。TFメンバーの方々と,デー夕を御提供い ただいた宇宙開発事業団，リモート・センシング技術 センターに厚く御礼申しあげる次第である。本研究の 一部に科学技術振興調整費総合研究「マイクロ波セン サデータ等リモートセンシング高度化のための基盤技
術開発」の研究費を使わせていただいた。最後に，兵 庫県南部地震の犠牲者の方々に心から哀悼の意を表し たい。

\section{[参考：入手データー覧］}
A. $\operatorname{SPOT}(\mathrm{P}, \mathrm{X})$
$91-10-23 / 322-280$
B. $\operatorname{SPOT}(P, X)$
95-1-20/322-280
C. $\operatorname{SPOT}(P, X)$
$95-1-21 / 322-280$
D. MOS (MESSR)
$95-1-19 / 23-71$
E. JERS (SAR)
$92-9-9 / 072-243$
F. JERS (SAR)
94-11-23/072-242
G. JERS (SAR)
$94-11-23 / 072-243$
H. JERS (SAR)
95-2-6/072-243 [一部 FD

版；ノイズ除去]

I . ERS (AMI)

94-10-12/072-243

J . ERS (AMI)

95-1-31/072-243

K. LANDSAT (TM) 95-1-24/110-036

L. KVR-1000

91-4

M. 空中写真（淡路北部，神戸地域）

N. 国土地理院数值地図 $(50 \mathrm{M}, 10000)$

O . JERS (SAR, OPS 立体視) $(95-2-6 / 072-243$ と 242)

P . JERS (SAR，OPS 立体視）(95-3-30/072-243と 242)

\section{文献}

1) 政春尋志：阪神・淡路大震災への国土地理院の取り組 みと災害対応への写真測量分野の課題. 写真測量とリ モートセンシング, Vol. 34，No. 4，pp. 57-62， 1995.

2 ) 海津優·藤原智・畑中雄樹·島田政信・児玉哲哉 (1995)： 測量の明日を占う（32）地殼変動アニメマップは可能 か?, 測量, 95-8, pp. 117-125, 1995.

3 ) 藤田和夫·前田保夫: 須磨地域の地質 (地域地質研究報 告, 5 万分の 1 図幅).地質調查所, 107p., 1984.

4 ) 水野清秀·服部仁-寒川旭・高橋浩：明石地域の地質(地 域地質研究報告, 5 万分の 1 図幅), 地質調查所, $90 \mathrm{p}$., 1990. 